\title{
Proinflammatory effect in whole blood by free soluble bacterial components released from planktonic and biofilm cells Jan Oscarsson $^{1}$, Maribasappa Karched ${ }^{\dagger 1,3}$, Bernard Thay ${ }^{\dagger 1}$, Casey Chen ${ }^{2}$ and Sirkka Asikainen*1
}

Address: ${ }^{1}$ Oral Microbiology, Department of Odontology, Umeå University, SE-90187 Umeå, Sweden, ${ }^{2}$ Primary Oral Health Care, USC School of Dentistry, University of Southern California, Los Angeles, CA90089-0641, USA and 3Department of Medical Biochemistry and Microbiology, Uppsala Biomedical Center, Uppsala University, SE-75123 Sweden

Email: Jan Oscarsson - jan.oscarsson@odont.umu.se; Maribasappa Karched - maribasappa.karched@imbim.umu.se; Bernard Thay - bernard.thay@odont.umu.se; Casey Chen - ccchen@usc.edu; Sirkka Asikainen* - sirkka.asikainen@odont.umu.se

* Corresponding author †Equal contributors

Published: 27 November 2008

BMC Microbiology 2008, 8:206 doi:10.1/86/147|-2180-8-206
Received: 18 June 2008

Accepted: 27 November 2008

This article is available from: http://www.biomedcentral.com//47|-2/80/8/206

(c) 2008 Oscarsson et al; licensee BioMed Central Ltd.

This is an Open Access article distributed under the terms of the Creative Commons Attribution License (http://creativecommons.org/licenses/by/2.0), which permits unrestricted use, distribution, and reproduction in any medium, provided the original work is properly cited.

\begin{abstract}
Background: Aggregatibacter actinomycetemcomitans is an oral bacterium associated with aggressive forms of periodontitis. Increasing evidence points to a link between periodontitis and cardiovascular diseases, however, the underlying mechanisms are poorly understood. This study investigated the pathogenic potential of free-soluble surface material, released from live planktonic and biofilm A. actinomycetemcomitans cells.
\end{abstract}

Results: By employing an ex vivo insert model (filter pore size $20 \mathrm{~nm}$ ) we demonstrated that the A. actinomycetemcomitans strain D7S and its derivatives, in both planktonic and in biofilm life-form, released free-soluble surface material independent of outer membrane vesicles. This material clearly enhanced the production of several proinflammatory cytokines (IL-I $\beta$, TNF- $\alpha$, IL-6, IL-8, MIP-I $\beta$ ) in human whole blood, as evidenced by using a cytokine antibody array and dissociationenhanced-lanthanide-fluorescent-immunoassay. In agreement with this, quantitative real-time PCR indicated a concomitant increase in transcription of each of these cytokine genes. Experiments in which the LPS activity was blocked with polymyxin B showed that the stimulatory effect was only partly LPS-dependent, suggesting the involvement of additional free-soluble factors. Consistent with this, MALDI-TOF-MS and immunoblotting revealed release of GroEL-like protein in freesoluble form. Conversely, the immunomodulatory toxins, cytolethal distending toxin and leukotoxin, and peptidoglycan-associated lipoprotein, appeared to be less important, as evidenced by studying strain D7S cdt/ltx double, and pal single mutants. In addition to A. actinomycetemcomitans a non-oral species, Escherichia coli strain IHE3034, tested in the same ex vivo model also released free-soluble surface material with proinflammatory activity.

Conclusion: A. actinomycetemcomitans, grown in biofilm and planktonic form, releases free-soluble surface material independent of outer membrane vesicles, which induces proinflammatory responses in human whole blood. Our findings therefore suggest that release of surface components from live bacterial cells could constitute a mechanism for systemic stimulation and be of particular importance in chronic localized infections, such as periodontitis. 


\section{Background}

Periodontitis is one of the most common chronic infections in humans, in which overgrowth of subgingival Gram-negative bacteria leads to chronic inflammation and gradual degradation of tooth-supporting tissues. The Gram-negative bacterium Aggregatibacter (Actinobacillus) actinomycetemcomitans is implicated in aggressive forms of periodontitis $[1,2]$. The oral cavity is its natural habitat, but the bacterium can also translocate from the oral cavity into the blood circulation, as evidenced by the occurrence of severe non-oral A. actinomycetemcomitans infections [3].

Increasing evidence points to a link between periodontitis and cardiovascular diseases [4-7]. However, the pathogenic mechanisms that would render periodontitis patients to increased cardiovascular risk are still poorly understood. Previous experimental studies on the background of the association between periodontitis and cardiovascular diseases have mainly worked on the basis of the infection hypothesis that suggests that chronic lowgrade bacterial and/or viral infections have a causal role in the development of atherosclerosis and its sequels, such as myocardial infarction and stroke $[8,9]$. It is believed that infections raise systemic inflammatory status, as evidenced by elevated circulating levels of proinflammatory cytokines and acute phase reactants, which in turn may promote endothelial dysfunction and proatherogenic and proinflammatory phenomena in arterial walls $[10,11]$.

Living bacteria can extend their pathogenicity by active extracellular release of surface components. A major route for the release of outer membrane components from Gram-negative bacteria is via shedding of outer membrane vesicles (OMV), which also allow the delivery of pathogenic effector proteins to eukaryotic target cells $[12,13]$. In addition, secretion of free-soluble outer membrane proteins (OMP) from bacterial cultures of e.g. Acinetobacter radioresistens and Escherichia coli could be suggested from previous studies [14-16], although the dependence of vesicles was not elucidated. Recently, we addressed the question whether live periodontal pathogens release free-soluble surface components, which could serve as an additional mechanism for spreading bacterial material from periodontal pockets to blood circulation. Interestingly, our results from an in vitro insert model, designed to control for bacterial viability and $\mathrm{OMV}$, demonstrated release of peptidoglycan-associated lipoprotein (PAL) and lipopolysaccharide (LPS) in addition to unidentified material from live planktonic A. actinomycetemcomitans cells, independent of OMV [17].

In periodontal pockets, bacteria grow on tooth surfaces as biofilms. Whether the biofilm bacteria also have the capability to release free-soluble surface material to the surrounding environment is not known. As $A$. actinomycetemcomitans PAL in purified form provoked proinflammatory responses in human whole blood ex vivo [17] we hypothesize that the extracellular release of freesoluble surface material from live A. actinomycetemcomitans cells could constitute a novel pathogenic mechanism that may be of particular importance in chronic localized infections, such as periodontitis. The present study was undertaken as, except for secretion via specialized secretory systems [18], there is limited knowledge of the proinflammatory effects of free-soluble surface material released from live Gram-negative bacteria. Our aim was to investigate in an ex vivo model the pathogenic potential of the pool of components released in free-soluble form by live planktonic and biofilm A. actinomycetemcomitans cells, and to make an attempt to delineate the identity of the secreted components.

\section{Results \\ Free-soluble material released by $\mathrm{A}$. actinomycetemcomitans induces proinflammatory responses in whole blood}

To study the pathogenic potential of free-soluble material released by $A$. actinomycetemcomitans cells, we implemented our cell culture plate insert model for stimulation of human whole blood as described in Methods. Similarly to our previous studies using the insert model [17], the absence of A. actinomycetemcomitans cell lysis in the wells during the experiments was confirmed by immunoblot analysis of samples taken from the wells outside the inserts (filtrates), using an antiserum raised against the cytoplasmic protein cyclic AMP receptor protein (CRP) (data not shown). In addition, plating revealed no apparent death of $A$. actinomycetemcomitans cells, or contamination in the wells (data not shown).

According to our findings from the cytokine antibody array analysis, used to screen for the cytokine responses in human whole blood, the free-soluble material released by strain D7S (rough-colony wild type), grown in planktonic form, caused clearly enhanced production of the interleukins IL-6 and IL-8, and of macrophage inflammatory protein (MIP-1 $\beta$ ), relative to no bacteria controls (Fig. $1 \mathrm{~A}-\mathrm{B})$. The same was observed when whole human blood was stimulated with free-soluble material released from $A$. actinomycetemcomitans strain D7SS (smooth-colony variant) (Fig. 1C-D). In addition, very similar results were obtained when whole blood from another donor was used (data not shown), indicating no apparent inter-individual differences. Interestingly, production of IL-6, IL-8 and MIP-1 $\beta$ was also induced when D7S cells grown in biofilm were used (Fig. 1E-F). This suggests that A. actinomycetemcomitans cell populations growing in biofilms also release free-soluble material with proinflammatory activity to the surrounding environment. Taken together, we concluded that the free-soluble components released 
(a)

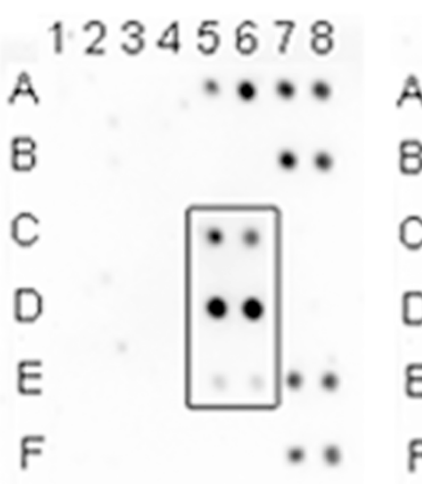

(c)

1.2345678

A

B

C

D

' $F$ (b)
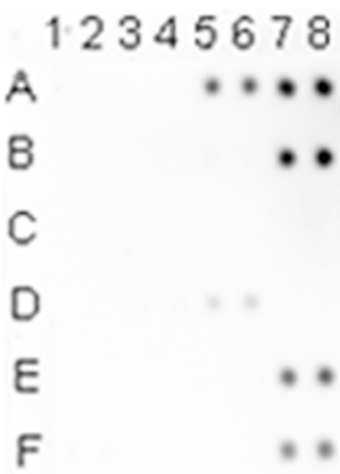

$*$ (e)

(d)
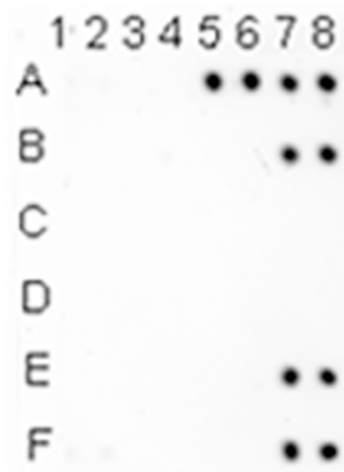

1.2345678

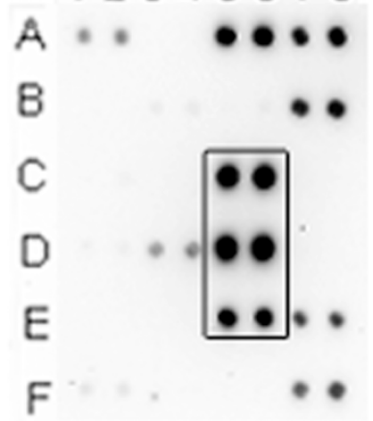

(g)

1.2345678

A

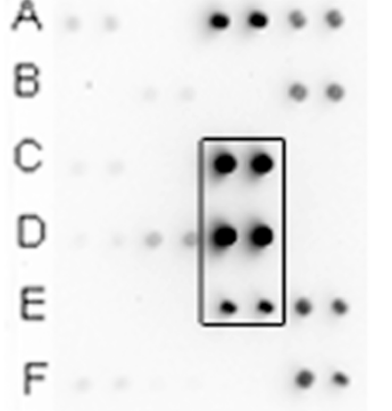

(f)

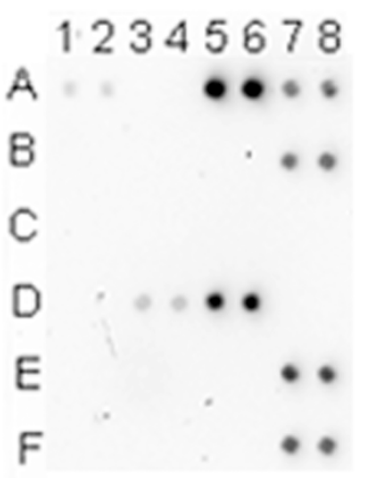

(h)

12345678

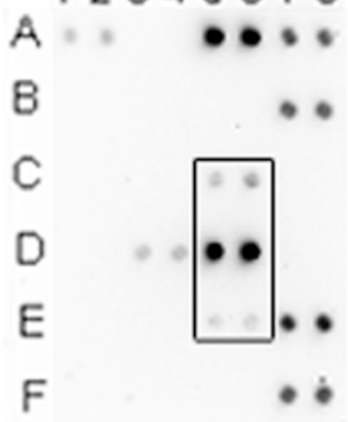

(i)

\begin{tabular}{|ccccc|}
\hline & 12 & 34 & 56 & 78 \\
\hline A & Eotaxin & IP-10 & Rantes & pos \\
B & GM-CSF & TNF- $\alpha$ & Leptin & pos \\
C & IL-1 $\alpha$ & IL-3 & IL-6 & neg \\
D & IL-1 $\beta$ & IL-4 & IL-8 & neg \\
E & IL-10 & IL-17 & MIP1 $1 \beta$ & pos \\
F & IL-12 & MIP1 $\alpha$ & MIP-5 & pos \\
\hline
\end{tabular}

Figure I

Cytokine induction in human whole blood by free-soluble material released by live $A$. actinomycetemcomitans cells. A cytokine antibody array was used to detect cytokines produced by human whole blood after stimulation for $6 \mathrm{~h}$ with free-soluble material released from A. actinomycetemcomitans as follows: planktonic D7S (panel a), and a corresponding negative control (panel b); planktonic D7SS (panel c), and a corresponding negative control (panel d); biofilm D7S (panel e), and a corresponding negative control (panel f); planktonic D7S $\Delta c d t / l t x$ in the absence (panel g) and in the presence (panel $h$ ) of polymyxin B (PMB). Serum (50\% in PBS) containing no bacteria served as negative controls. The locations of cytokine antibodies and positive (pos) and negative (neg) controls on the array are indicated (panel i). 
by live A. actinomycetemcomitans cells, grown either planktonic or in biofilm, could indeed induce proinflammatory effects in whole blood.

\section{Free-soluble material released by $\mathrm{A}$.}

\section{actinomycetemcomitans stimulates TNF- $\alpha$ and IL-I $\beta$} production in whole blood

According to the above-described cytokine analyses (Fig. 1) the free-soluble material released from the test strains appeared to have no effect on the production of TNF- $\alpha$ and IL-1 $\beta$. As a previous report indicated increased production of these cytokines in human whole blood, stimulated with A. actinomycetemcomitans LPS [19], the levels of TNF- $\alpha$ and IL- $1 \beta$ were also quantified using a highly sensitive approach (Dissociation enhanced lanthanide fluorescence immuno a assay; DELFIA [see Methods]). As shown in Fig. 2, a significant increase in both TNF- $\alpha$ (10.3-fold) and IL-1 $\beta$ (4.2-fold) production was detected when whole human blood was stimulated with free-soluble material released from planktonic D7S cells in the cell culture model (see Methods), relative to no bacteria con-
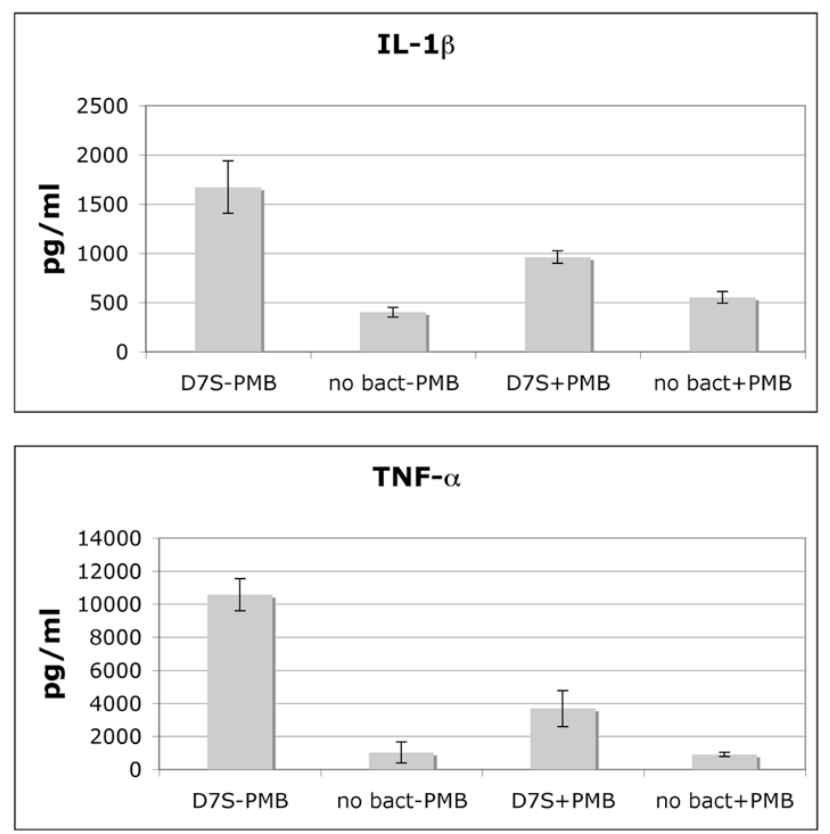

Figure 2

Induction of IL-I $\beta$ and TNF- $\alpha$ production in human whole blood by free-soluble material released by live A. actinomycetemcomitans cells. DELFIA was used to quantify the levels of IL-I $\beta$ and TNF- $\alpha$ in human whole blood after stimulation with planktonic $A$. actinomycetemcomitans strain D7S for $6 \mathrm{~h}$. Serum (50\% in PBS) containing no bacteria served as negative controls. The stimulation was done in the presence (+PMB) and in the absence (-PMB) of polymyxin $B$. Shown are the means and standard deviations from three independent experiments $(P<0.05)$. trols. Why this was not seen using the cytokine array (Fig. 1) is unclear. According to our findings (Fig. 2), the increase in TNF- $\alpha$ and IL- $1 \beta$ production was less pronounced in the presence of polymyxin $\mathrm{B}$ (PMB), which blocks LPS activity [20]. However, there was still a clear upregulation (4.1-fold and 1.7-fold, respectively), indicative of an LPS-independent effect on TNF- $\alpha$ and IL- $1 \beta$ production. Thus, we concluded that in addition to IL-6, IL-8 and MIP- $1 \beta$, the production of TNF- $\alpha$ and IL- $1 \beta$ in whole blood was also enhanced by the free-soluble material released by D7S.

\section{Free-soluble material released by $\mathrm{A}$.}

\section{actinomycetemcomitans enhances cytokine gene} transcription in whole blood

To confirm our observations of increased production of the above proinflammatory cytokines and chemokines in stimulated whole blood (Fig. 1 and Fig. 2, the amount of transcript of each gene was quantified using quantitative real-time PCR (qRT-PCR). As indicated in Fig. 3, there was up to 1000 -fold increased transcription of each cytokine gene when human blood was stimulated with free-soluble material released from planktonic D7S cells relative to no bacteria controls. Although the increase in cytokine gene transcription was less intensive (up to 100-fold) when the whole blood stimulation was done in the presence of PMB (Fig. 3), each gene was still clearly upregulated, indicating that this effect was also LPS-independent. We could therefore conclude that transcription of IL-6, IL-8, MIP$1 \beta$, TNF- $\alpha$ and IL-1 $\beta$ in whole blood was enhanced by the free-soluble material released by D7S.

\section{LPS-independent cytokine stimulation in whole blood: possible involvement of additional factors released in free- soluble form}

As the free-soluble material released by strain D7S provoked proinflammatory responses in human whole blood also independently of LPS, we investigated the possibility that this was due to release of leukotoxin A (LtxA) and/or cytolethal distending toxin (CDT). These immunomodulatory toxins were earlier shown to be extracellularly secreted by A. actinomycetemcomitans [21,22]. To test the contribution of LtxA and CDT we constructed a derivative of strain D7S having both the ltxA and $c d t A B C$ gene loci deleted (see Methods). The abolished production of LtxA was confirmed by immunoblotting, using specific antibodies (Fig. 4). According to our findings using the ex vivo insert model for stimulation of whole blood, inactivation of $c d t A B C$ and $l t x A$ had no major effect. Instead, the freesoluble material released by the D7S double mutant, grown in planktonic form, induced a proinflammatory response in whole blood similar to that of the parental strain, D7S (Fig. 1A-B), i.e. production of IL-6, IL-8, and MIP-1 $\beta$ was clearly enhanced (Fig. 1G) relative to no bacteria controls (Fig. 1F). When this experiment was carried 

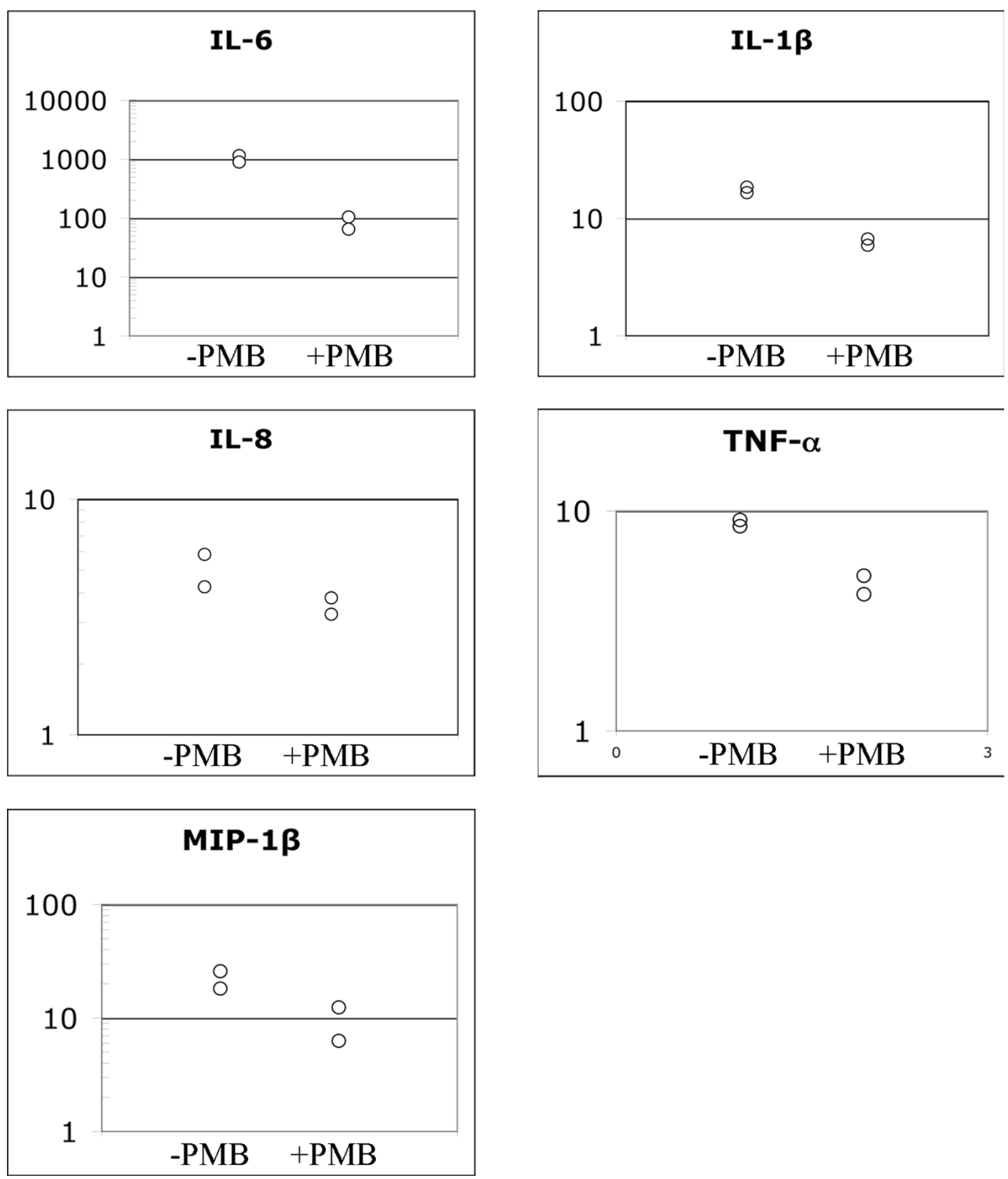

Figure 3

Induction of cytokine gene transcription in human whole blood by free-soluble material released by live $A$. actinomycetemcomitans cells. qRT-PCR was used to quantify the levels of IL-I $\beta$, IL-6, IL-8, MIP-I $\beta$, and TNF- $\alpha$ mRNA in human whole blood after stimulation with planktonic $A$. actinomycetemcomitans strain D7S for $6 \mathrm{~h}$. The stimulation was done in the presence (+PMB) and in the absence (-PMB) of polymyxin B. Shown is the increase (fold change) of each cytokine mRNA in whole blood stimulated with strain D7S relative to no bacteria controls (50\% serum in PBS) from two separate experiments ( $P$ $<0.05)$. 

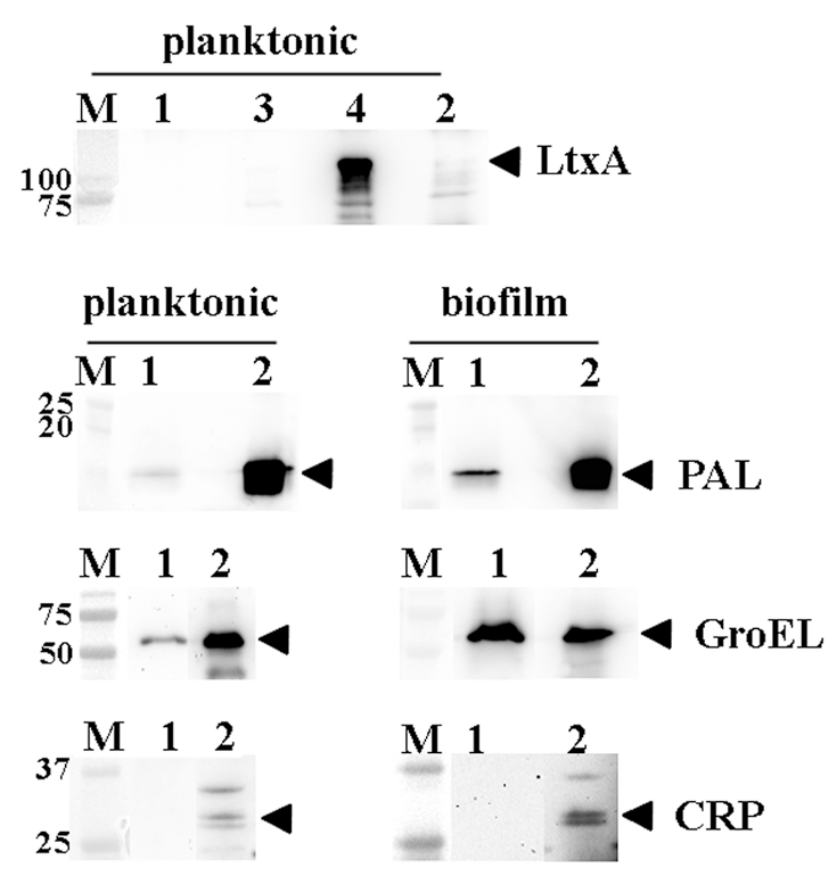

Figure 4

Immunoblot detection of proteins released in freesoluble form by biofilm and planktonic $A$. actinomycetemcomitans strains, using polyclonal antisera raised against LtxA, PAL, GroEL, and CRP (lysis marker), respectively. Proteins released from strain D7S to PBS through the $20 \mathrm{~nm}$ filters of the inserts were collected after $6 \mathrm{~h}$ of incubation and a concentrated sample (denoted I) equal to $0.75 \mathrm{ml}$ filtrate was applied on the gels where indicated. The following whole cell preparation samples ( $10 \mu \mathrm{g}$ protein each) were loaded as controls where indicated: 2 . D7S, 3. D7S $\triangle c d t A B C / l t x A$, and 4. JP2 (high producer of LtxA [56]). The sizes of the proteins $(\mathrm{kDa})$ in the prestained molecular weight marker $(M)$ are indicated. The reactive band corresponding to each protein is indicated with an arrow.

out in the presence of PMB (Fig. 1H) to inhibit LPS activity, the production of these cytokines was still induced relative to no bacterial controls (Fig. 1F), again indicating LPS-independent stimulation. However, the cytokine stimulation was less intensive, compared to when $\mathrm{PMB}$ was absent (Fig. 1G). Lack of contribution of LtxA and CDT to cytokine stimulation in human whole blood is consistent with the absence of these toxins in the filtrates released by strain D7S to PBS, which was also confirmed by immunoblotting (Fig. 4 and data not shown).

As PAL was identified in the free-soluble material released by both D7S and D7SS [17](Fig. 4), a pal mutant derivative (D7SS-p) was subsequently tested in the ex vivo model. According to our results, the free-soluble material released by planktonic D7SS-p induced a cytokine response in whole blood very similar to that of the parental strain, D7SS (data not shown). These findings together suggest that other factor(s) released in free-soluble form by A. actinomycetemcomitans may be involved in the induction of proinflammatory responses in whole blood.

\section{GroEL-like protein is a major protein released in free- soluble form by $A$. actinomycetemcomitans D7S}

To obtain more information about the free-soluble proteins secreted by A. actinomycetemcomitans, we used the cell culture insert model with PBS instead of serum/whole blood (see Methods). Plating revealed no apparent death of $A$. actinomycetemcomitans cells, or contamination in the wells (data not shown). As in our previous studies using the insert model [17], the absence of A. actinomycetemcomitans cell lysis in the wells during the experiments was confirmed by immunoblot analysis of filtrates, using an antiserum raised against the cytoplasmic protein, CRP (Fig. 4). SDS-PAGE analysis of filtrates from D7S and D7SS, grown both planktonic and in biofilm form (Fig. $5 \mathrm{~A})$, revealed several bands after Silver staining. Finding similar band profiles of material released through the 20 $\mathrm{nm}$ pores of the inserts from both D7S and D7SS is in accordance with the cytokine induction by these strains as determined by the present antibody array (Fig. 1).

Since our results hitherto obtained with D7S and D7SS were very similar with each other, we continued our analyses mainly using filtrates from D7S. As shown in Fig. 5B, two major protein bands could be detected in filtrates from D7S, by using Coomassie staining. These bands represented proteins of approximate molecular masses of 60 and $15 \mathrm{kDa}$, respectively. Bands of these sizes (Fig. 5C and data not shown) were also obtained with immunoblot analysis of the D7S filtrates, using an antiserum raised against whole-cell antigen of $A$. actinomycetemcomitans serotype a. Our previous results show that this antiserum reacts to multiple epitopes in A. actinomycetemcomitans [23]. Our current findings (Fig. 5C) therefore suggest that the 60 and $15 \mathrm{kDa}$-proteins are the two major protein antigens released in free-soluble form under the present conditions. As the $15 \mathrm{kDa}$-protein band was not detected in filtrates from the pal-deficient strain D7S-p (Fig. 5B), we concluded that this protein band represents PAL. This was consistent with immunoblotting (Fig. 4 and data not shown).

To determine the identity of the $60 \mathrm{kDa}$ protein we used MALDI-TOF-MS, which identified A. actinomycetemcomitans GroEL-like protein (Hsp60; Cpn60) (Swiss-Prot entry P46398). The release of GroEL-like protein in free-soluble form to PBS by both planktonic and biofilm D7S was confirmed using immunoblotting and an antiserum raised against E. coli GroEL (Fig. 4). According to SDS-PAGE (Fig. 5), the pal-deficient strain D7S-p released a higher amount 

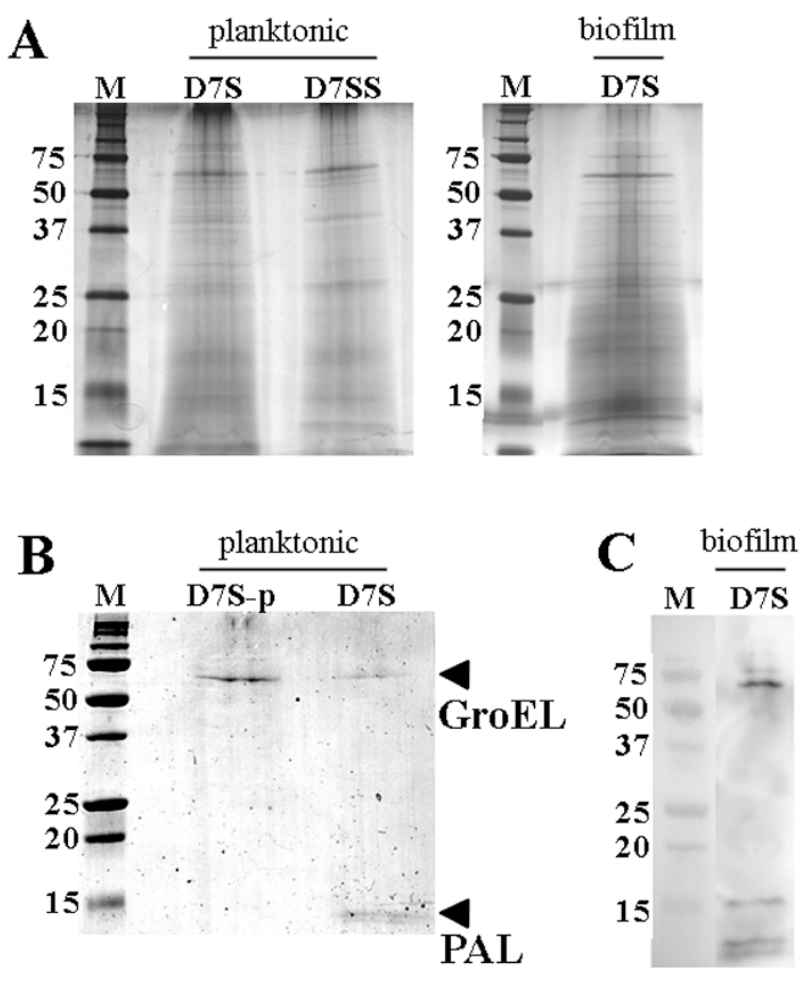

Figure 5

SDS-PAGE analysis of proteins released in free-soluble form by biofilm and planktonic A. actinomycetemcomitans D7S, its isogenic pal mutant (D7S-p), or D7SS, detected by Silver-staining (panel A), by Coomassie blue-staining (panel B), and by immunoblotting using an antiserum raised against whole cell antigen of $A$. actinomycetemcomitans serotype a (panel C). Proteins released to PBS through the $20 \mathrm{~nm}$ filters of the inserts were collected after $6 \mathrm{~h}$ of incubation. Concentrated samples equal to $1.5 \mathrm{ml}$ filtrate were applied in each well for Silver- and Coomassie blue-staining, and equal to $0.75 \mathrm{ml}$ for immunoblotting. Protein bands corresponding to GroEL and PAL are indicated with arrows. The sizes of the proteins $(\mathrm{kDa})$ in the prestained molecular weight marker $(M)$ are indicated.

of GroEL-like protein than the parental strain. This observation is consistent with the role of the Tol-Pal complex in maintaining outer membrane integrity [24,25]. Taken together, we could conclude that GroEL-like protein is a major protein released in free-soluble form by A. actinomycetemcomitans D7S.

\section{Release of free-soluble material with proinflammatory effect by $\mathrm{E}$. coli 018}

To assess the specificity of our present findings to A. actinomycetemcomitans, the ex vivo culture insert model (Meth- ods), controlled as above (Fig. 6 and data not shown), was used to stimulate human whole blood with free-soluble material released from planktonic E. coli strain IHE3034 (serotype O18:K1:H7). As shown in Fig. 7A-C, there was a clear stimulation of IL- 6 , IL- 8 , and MIP- $1 \beta$ relative to no bacterial controls, indicative of a proinflammatory effect in whole blood caused by the E. coli free-soluble material. This observation is in accordance with previous studies using E. coli strains J5 and 789 (serotypes O18:K1:H7 and O78, respectively) $[14,15]$, which demonstrated the release of Outer Membrane Protein A (OmpA), a prime target of the host immune system $[26,27]$. The release of OmpA in free-soluble form to PBS by planktonic IHE3034 was confirmed using immunoblotting and an antiserum against OmpA (Fig. 6). OMV-independent secretion of
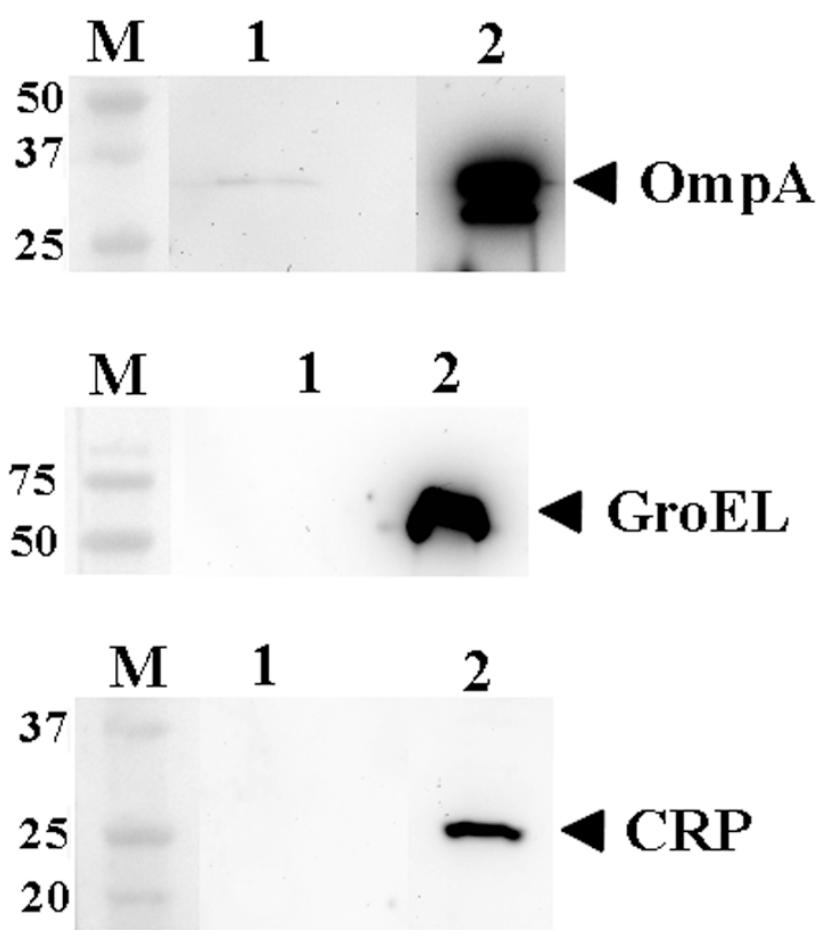

\section{Figure 6}

Immunoblot detection of proteins released in freesoluble form by planktonic $E$. coli strain IHE3034, using polyclonal antisera raised against OmpA, GroEL, and CRP (lysis marker), respectively. Proteins released to PBS through the $20 \mathrm{~nm}$ filters of the inserts were collected after $6 \mathrm{~h}$ of incubation and a concentrated sample (denoted I) equal to $0.75 \mathrm{ml}$ filtrate was applied on the gels where indicated. Whole cell preparation samples (denoted 2; $10 \mu \mathrm{g}$ protein each) of strain IHE3034 were loaded as controls where indicated. The sizes of the proteins $(\mathrm{kDa})$ in the prestained molecular weight marker $(M)$ are indicated. The reactive band corresponding to each protein is indicated with an arrow. 
(a)

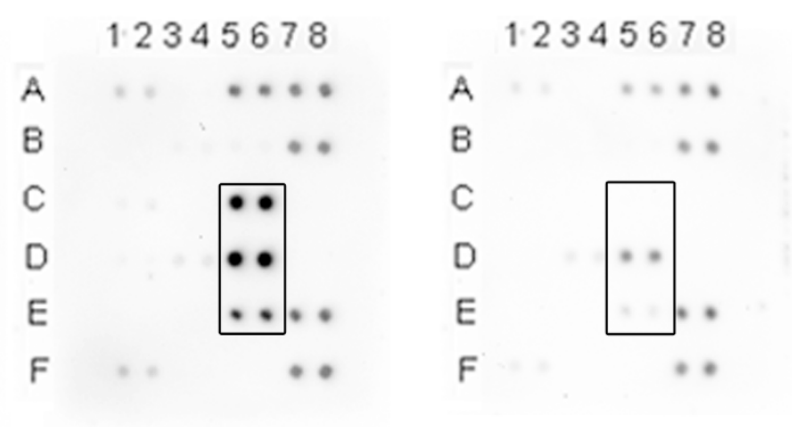

(c)

\begin{tabular}{|ccccc|}
\hline & $\mathbf{1 2}$ & $\mathbf{3 4}$ & $\mathbf{5 6}$ & $\mathbf{7} \mathbf{8}$ \\
\hline A & Eotaxin & IP-10 & Rantes & pos \\
B & GM-CSF & TNF- $\alpha$ & Leptin & pos \\
C & IL-1 $\alpha$ & IL-3 & IL-6 & neg \\
D & IL-1 & IL-4 & IL-8 & neg \\
E & IL-10 & IL-17 & MIP $1 \beta$ & pos \\
F & IL-12 & MIP $1 \alpha$ & MIP-5 & pos \\
\hline
\end{tabular}

\section{Figure 7}

Cytokine induction in human whole blood by freesoluble material released by live $E$. coli. A cytokine antibody array was used to detect cytokines produced by human whole blood after stimulation for $6 \mathrm{~h}$ with free-soluble material released from planktonic E. coli IHE3034 (panel a), compared with a corresponding negative control (serum $[50 \%$ in PBS] containing no bacteria) (panel b). The experiment was carried out in the presence of polymyxin B (PMB). The locations of cytokine antibodies and positive (pos) and negative (neg) controls on the array are indicated (panel c).

OmpA by E. coli is consistent with subcellular localization studies, finding OmpA in the fraction of soluble secreted proteins in addition to vesicles [14]. In contrast to OmpA, GroEL was absent from these filtrates (Fig. 6). This is in agreement with the cytoplasmic localization of GroEL and its presence in OMVs released by E. coli [28]. Our results therefore show that release of free-soluble surface material with proinflammatory effects in human whole blood is not restricted to A. actinomycetemcomitans.

\section{Discussion}

Our present findings using an experimental setup (cell culture insert model) designed to exclude the presence of OMV and bacterial death or lysis in the samples, demonstrated that $A$. actinomycetemcomitans biofilms can release free-soluble surface material. This is consistent with our previous results showing extracellular release of free-soluble surface material (LPS and various proteins) from live planktonic A. actinomycetemcomitans cells [17]. This apparently novel, yet uncharacterized mechanism to release soluble material from biofilm to the surrounding environment could be of significance in periodontal pockets, where the biofilm life-form provides persistent bacterial colonization on tooth surfaces. Our present results on E. coli show (Fig. 6, 7), however, that release of free-soluble surface material is not restricted to A. actinomycetemcomitans, but may differ between bacteria.

By employing the cell culture insert model, we also showed that the released free-soluble material not only from planktonic but also from biofilm A. actinomycetemcomitans promoted proinflammatory responses in blood, i.e. IL-1 $\beta$, IL-6, IL- 8, MIP- $1 \beta$ and TNF- $\alpha$ (Fig. $1,2,3$ ). This is in agreement with our previous results showing that in addition to elevated serum antibody response to periodontal pathogens in periodontitis patients $[29,30]$, purified A. actinomycetemcomitans components induced proatherogenic (foam cells) and/or proinflammatory (cytokines) responses from murine macrophages [31] as well as production of proinflammatory cytokines and chemokines (IL-6, IL-8, and MIP-1 $\beta$ ) from human whole blood [17].

The number of live bacteria $\left(1-4 \times 10^{8} / \mathrm{ml}\right.$ serum) in the present ex vivo model exceeded the expected blood concentrations of cultivable bacteria in chronic infections. In serious acute infections the circulating bacterial concentrations appear to be substantially higher by DNA-based than by culture methods as exemplified by a study on meningitis: Neisseria meningitidis genome copy density in blood samples ranged from $10^{4}$ to $10^{8} / \mathrm{ml}$ in patients' blood, although it is likely that these figures also contained dead bacteria [32]. On the other hand, in biofilms bacteria can grow in numbers comparable to our test inoculum [33] and they may release free-soluble material to surrounding tissues or circulation on long-term basis.

Although a substantial stimulatory effect on the production of proinflammatory cytokines in blood was due to LPS, there also was a marked LPS-independent stimulation, which prompted us to also survey the contents of the released free-soluble material. A. actinomycetemcomitans has previously been shown to extracellularly secrete two toxins with immunomodulatory activity, leukotoxin A (LtxA) and cytolethal distending toxin (CDT) [21,22]. To assess the contribution of these toxins to cytokine stimulation in whole blood we constructed and tested a novel ItxA cdtABC double-deletion mutant derived from a clinical isolate, A. actinomycetemcomitans strain D7S. However, as the free-soluble material released from the double 
mutant had a stimulatory activity, very similar to that secreted from the wildtype strain (Fig. 1), we concluded that released components other than these toxins are likely to be of greater significance. This observation is consistent with our present immunoblot analyses suggesting the absence of LtxA and CDT from D7S filtrates (released to PBS). The lack of LtxA in the filtrates could be a combined result of low levels of leukotoxin produced by D7S under the experimental conditions used (Fig. 4), and of the association of leukotoxin with OMV [34]. It is possible that this could be the case also for CDT, analogous with its association with OMV in E. coli [28]. In line with our previous findings using planktonic $A$. actinomycetemcomitans [17], the outer membrane lipoprotein, PAL, was also released in free-soluble form from biofilms (Fig. 4). However, similarly to LtxA and CDT, we did not see a contribution of PAL to cytokine stimulation by using cytokine antibody arrays, i.e. inactivation of pal had no apparent effect in this experimental setup. This is in contrast to our previous findings that purified PAL stimulated proinflammatory cytokines in whole blood [17]. This discrepancy from the present whole-cell experiment might be a result of enhanced release of LPS in the pal deficient mutant strain [17].

In addition to having a crucial role in protein-folding, vital for cell survival during stress [35,36], GroEL (Hsp60; Cpn60)-like proteins from several bacteria, including $A$. actinomycetemcomitans, can activate a plethora of mammalian cells, including macrophages, keratinocytes and periodontal ligament epithelial cells [37-41]. Interestingly, our MALDI-TOF-MS and immunoblot results (Fig. 4, 5) revealed that both bacterial phenotypes, biofilm-form and planktonic A. actinomycetemcomitans, released significant amounts of GroEL-like protein in free-soluble form. This observation is consistent with previous studies in which GroEL-like protein was localized to the surface of $A$. actinomycetemcomitans $[37,42]$, as in several other bacteria, e.g. Borrelia burgdorferi, Helicobacter pylori, Haemophilus ducreyi, and Legionella pneumophila [43-48]. This supports the previously postulated hypothesis that bacterial GroELlike proteins may act as direct cell-to-cell virulence factors for host cells [49], albeit the release mechanism is not yet understood. Furthermore, due to the molecular mimicry, the immune response to bacterial GroEL could crossreact with human Hsp60 expressed on endothelial cells, leading to inflammatory reactions. This is supported by finding bacterial GroEL within atherosclerotic lesions in close association with activated inflammatory cells [50], adding further evidence to the involvement of persistent infections such as periodontitis, with atherosclerosis. However, the specific contribution of GroEL to the proinflammatory responses induced in human whole blood would be difficult to assess as this protein is essential for bacterial growth [51]. It also appears to copurify with LPS, suggest- ing a physical association between these two molecules $[52,53]$. Analogous to this, it was recently demonstrated that human Hsp60 bound bacterial LPS and synergistically enhanced LPS-induced innate and adaptive immune responses [54]. Thus, the exact nature of the released material that lead to the LPS-independent proinflammatory effects in whole blood is yet to be identified.

Taken together, our present data support that, if entered into the blood circulation, the free-soluble material released from A. actinomycetemcomitans has potential to induce proinflammatory responses that are considered important in atherogenesis and used as biomarkers of an elevated risk of cardiovascular events [55]. Within the limitations of our single-species biofilm experiments, we suggest that the release of free-soluble bacterial material from live subgingival biofilms may be a crucial mechanism how chronic inflammation in tooth-supporting tissues is perpetuated and systemic dissemination and immunostimulation are sustained. After entering the parenteral space through the ulcerated periodontal pocket epithelium, free-soluble material may readily gain access into the abundant blood/lymph vascular network immediately under the epithelium, which then opens the route for systemic spread. The hypothesis of the release of freesoluble surface material by live biofilm bacteria, independent of OMV, is new, and although not restricted to oral microorganisms (Fig. 6, 7), it may help extending the knowledge of mechanisms for the host's exposure to pathogenic material originating from the bacterial biofilm in this unique nonparenteral ecological habitat. The next step involves testing the hypothesis in in vivo models due to the obvious restrictions in simulating responses to circulating bacterial material by using blood without knowledge of other immunoinflammatory responses of the challenged host.

\section{Conclusion}

Our present study demonstrates that A. actinomycetemcomitans, grown in biofilm and planktonic form, releases freesoluble surface material independent of outer membrane vesicles, and that this material induces proinflammatory responses in human whole blood. Our findings therefore suggest that release of surface components from live bacterial cells could constitute a mechanism for systemic stimulation and be of particular importance in chronic localized infections, such as periodontitis.

\section{Methods}

\section{Bacterial strains and culturing conditions}

A. actinomycetemcomitans serotype a strains D7S (rough colony type) and D7SS (smooth colony type), their corresponding PAL-deficient mutants, D7SS-p [23] and D7S-p [17], strain D7S $\Delta l t x / c d t$ (this work), and the leukotoxin highly producing strain, JP2 [56], were all cultured on 
blood agar plates (5\% defibrinated horse blood, $5 \mathrm{mg}$ hemin/l, $10 \mathrm{mg}$ Vitamin K/l, Columbia agar base) incubated in air supplemented with $5 \% \mathrm{CO}_{2}$, at $37^{\circ} \mathrm{C}$ for $3 \mathrm{~d}$ as previously described [17]. Escherichia coli IHE3034 (serotype O18:K1:H7) isolated from meningitis [57] was cultivated $16-18 \mathrm{~h}$ on blood agar as described above. For biofilm growth, $2 \times 10^{8}$ bacterial cells were inoculated in $2 \mathrm{ml}$ tryptic soy broth (Difco) in 24-well cell culture plates (Nunc), which were incubated in static culture in air supplemented with $5 \% \mathrm{CO}_{2}$, at $37^{\circ} \mathrm{C}$ for $3 \mathrm{~d}$. Biofilms were stained with crystal violet as previously described [58] and the amount of bound dye, which is proportional to the biofilm mass was quantitated by measuring its absorbance at $590 \mathrm{~nm}$.

\section{Construction of markerless mutations}

The D7S ltxA cdtABC markerless double-deletion mutant was constructed using the Cre/loxP recombination system, as described previously [59]. In brief, two DNA fragments flanking the target deletion site were generated by PCR and cloned into upstream and downstream loxP sites of the vector pLox2-Spe [59], which carries a Spe-resistance $\left(\mathrm{Spe}^{\mathrm{R}}\right)$ cassette flanked by loxP sites. The recombinant plasmid was subsequently introduced into strain D7S, using natural transformation [60], selecting for spectinomycin-resistant transformants. The replacement of the target gene with loxP-Spe cassette-loxP was confirmed by PCR sequencing. The Spe cassette in the transformants was then removed by introducing the plasmid pAT-Cre [61], carrying the Cre recombinase. The removal of the Spe cassette was also confirmed by DNA sequence analysis. The resultant mutants had the $c d t A B C$ operon replaced by a loxP site spacer AGATCTGC, and the ltxA gene replaced by a loxP site with spacer ATGTATAC. This double-deletion strain construct was confirmed by PCR analysis, using the primer pairs CDT1 (5'-GGAGGCGATAACTCTACATCAGG-3') and CDT2 (5'-GTGTCACGTCGTCAAGCCGATG-3'), and LTX1 (5'CTACTACGGGACCTGTCGCAGG-3') and LTX2 (5'-CCGGCTTTAGTAGCATTACGACCG-3'), respectively.

\section{Whole blood stimulation}

All procedures were conducted in accordance with the guidelines of the local ethics committee at the Medical Faculty of Umeå University, which are in compliance with the Declaration of Helsinki (59 $9^{\text {th }}$ WMA General Assembly, Seoul, October 2008). Blood was drawn from a healthy volunteer, after informed consent, from antecubital vein into blood collection tubes containing heparin (BD Biosciences). A cell culture insert model, described previously [17], was then used to expose the whole blood to free-soluble components released by live A. actinomycetemcomitans and E. coli cells. For whole blood stimulation using planktonic bacteria, bacterial cells (final concentration 1 $\times 10^{8} \mathrm{CFU} / \mathrm{ml}$ ) were suspended in serum (50\% in PBS), separated from the same whole blood. The bacterial suspension $(500 \mu \mathrm{l})$ was then added to cell culture inserts of pore size $20 \mathrm{~nm}$ (Nunc). The inserts were placed into the wells of a 24-well cell culture plate (Nunc), containing $500 \mu \mathrm{l}$ whole blood. Serum (50\% in PBS) containing no bacteria served as a negative control. The cell culture plate was subsequently incubated for $6 \mathrm{~h}$ at $37^{\circ} \mathrm{C}$ in air supplemented with $5 \% \mathrm{CO}_{2}$.

For whole blood stimulation using biofilm bacteria, $A$. actinomycetemcomitans biofilms (grown $3 \mathrm{~d}$ in 24-well cell culture plates; approximately $2 \times 10^{8} \mathrm{CFU}$ ) were gently washed with PBS and then $500 \mu \mathrm{l}$ serum (50\% in PBS) was added to the wells. Human blood $(500 \mu \mathrm{l})$ was then added to cell culture inserts of pore size $20 \mathrm{~nm}$ (Nunc), which were placed into the wells with biofilm. The cell culture plate was subsequently incubated as above. When indicated, experiments were performed with PMB (final concentration: $30 \mu \mathrm{g} / \mathrm{ml}$ ), an inhibitor of LPS activity [20], to roughly estimate the extent of LPS-independent cytokine stimulation. Similarly to other authors [62], we did not use heat treatment of samples as this has been shown to reduce the cytokine-inducing activity of LPS [6365].

For RNA isolation from stimulated whole blood, $100 \mu \mathrm{l}$ blood was removed from the wells after $6 \mathrm{~h}$ of incubation and processed as described below. The remaining volume $(400 \mu \mathrm{l})$ of stimulated whole blood was centrifuged $5 \mathrm{~min}$ at $5000 \times$ g. Supernatants were stored at $-80^{\circ} \mathrm{C}$ until cytokine analysis and profiling (see below).

The cell culture insert model was controlled for viability of the bacteria, absence of bacterial lysis, and the absence of bacterial contamination of the material released through the insert filters (filtrates) as described previously [17]. In brief, aliquots from within and outside the inserts were plated on blood agar plates, which were incubated as above for $3 \mathrm{~d}$. Filtrates were also analyzed with immunoblotting, using an antiserum raised against the cytoplasmic protein cyclic AMP receptor protein (CRP). Biofilm integrity was confirmed by crystal violet staining as described previously [66] and also by plating aliquots taken from above the biofilms on blood agar.

\section{Analysis of free soluble proteins released by live $\mathbf{A}$. actinomycetemcomitans and $\mathrm{E}$. coli cells}

For this, the cell culture insert model was employed and controlled as described above, however with the exception that PBS was used instead of serum or blood. After 6 $\mathrm{h}$ of incubation at $37^{\circ} \mathrm{C}$ in air supplemented with $5 \%$ $\mathrm{CO}_{2}$, filtrates were collected and precipitated with acetone ( $80 \%$ final concentration) prior to SDS-PAGE analysis. Selected protein bands after Coomassie blue staining were subject to MALDI-TOF-MS analysis at the Umeå Protein 
Analysis Facility, Department of Chemistry, Umeå University.

\section{SDS-PAGE and Western immunoblotting}

The procedures employed for SDS-PAGE and immunoblot analysis have been described previously [23]. For immunoblots we used the following polyclonal antibodies raised in rabbits against $A$. actinomycetemcomitans LtxA [67] and PAL [68], E. coli GroEL (Sigma-Aldrich), E. coli OmpA [69], H. ducreyi Cdt [70], V. cholerae CRP [71], and against whole cells of A. actinomycetemcomitans serotype a [72]. Antisera were used at final dilutions of 1:1000, except for the antisera raised against GroEL (1:8000), PAL $(1: 10000)$, and OmpA $(1: 10000)$. Horseradish peroxidase-conjugated anti-rabbit secondary antibodies were used at a final dilution of 1:10000. Immunoreactive bands were visualized using SuperSignal ${ }^{\circledast}$ (Pierce, Rockford, IL, USA).

\section{Quantification of cytokine production}

To obtain a profile of the cytokines produced by human whole blood after stimulation with released free-soluble bacterial material, a cytokine antibody array (TranSignal ${ }^{\mathrm{TM}}$ Human Cytokine Antibody Array 1.0; Panomics, Redwood City, CA, USA), allowing simultaneous detection of the levels of 18 cytokines, was used according to instructions from the manufacturer. Dissociation enhanced lanthanide fluorescence immuno assay [73] was used for the quantification of the amounts of IL- $1 \beta$ and TNF- $\alpha$ produced by human whole blood. For this, 96-well microtiter plate wells were coated with capture-antibodies against human IL-1 $\beta$ and TNF- $\alpha$ (200 ng/well) and incubated overnight at $4{ }^{\circ} \mathrm{C}$ with shaking. The wells were washed with DELFIA wash buffer twice and saturated with $1.5 \%$ BSA in water for $6 \mathrm{~h}$ at RT. The wells were then washed twice with $0.9 \mathrm{M} \mathrm{NaCl}$ and stabilized at RT for $15 \mathrm{~h}$. Samples and the standards (recombinant IL- $1 \beta$ and TNF- $\alpha$, eBioscience), each in triplicates, were added to the wells and incubated at RT for $1 \mathrm{~h}$. After washing as above twice, detection antibodies against human IL-1 $\beta$ (Europiumlabelled) and TNF- $\alpha$ (Samarium-labelled) were added to the wells (200 ng/well) and incubated at RT for $1 \mathrm{~h}$. The wells were subsequently washed six times as above, and then $200 \mu$ l DELFIA enhancement solution was added to each well and the plates were incubated at RT on a shaker for $15 \mathrm{~min}$. Europium and Samarium signals were measured using a multilabel reader (Victor ${ }^{3}$, Perkin Elmer).

\section{Quantitative real-time PCR analysis}

Total RNA from whole blood was isolated from two separate stimulation experiments, using the RiboPure ${ }^{\mathrm{TM}}$-Blood kit (Ambion Inc.) according to instructions of the manufacturer. Quantitative real-time PCR was performed using the 7900HT Real-time PCR system (Applied Biosystems). Concentration of RNA was determined by measuring the absorbance at $260 \mathrm{~nm}$. One $\mu \mathrm{g}$ of total RNA was converted to cDNA using Transcriptor First Strand cDNA Synthesis Kit (Roche) according to instructions from the manufacturer. Each qRT-PCR reaction (final volume $5 \mu \mathrm{l}$ ) was run in triplicates, containing $1 \times \mathrm{SYBR}^{\circledast}$ Green PCR Master Mix (Applied Biosystems), and with the cDNA diluted 100x (1000x in addition to assess PCR efficiency). The sequences and final concentrations of the forward and reverse oligonucleotide primers used in qRT-PCR are indicated in Table 1. The qRT-PCR data were normalized to an endogenous control ( $\beta$-actin).

\section{Statistical analysis}

Unless otherwise stated all experiments were repeated three times. Mann-Whitney U test was used to assess the statistical significance of differences between experimental and control treatment of whole blood, observed using DELFIA and qRT-PCR. P-values of less than 0.05 were regarded as statistically significant.

\section{Authors' contributions}

JO was responsible for general experimental design, qRTPCR setup, research supervision, data analysis and inter-

Table I: Oligonucleotides used in the qRT-PCR reactions

\begin{tabular}{|c|c|c|c|c|}
\hline mRNA target & Oligonucleotide (F: forward; R: reverse) & Final concentration $(\mathrm{nM})$ & Amplicon length (bp) & Source \\
\hline \multirow[t]{2}{*}{$\beta$-actin } & F: 5'-GGATGCAGAAGGAGATCACTG-3' & 300 & 90 & [74] \\
\hline & R: 5'-CGATCCACACGGAGTACTTG-3' & 300 & & \\
\hline \multirow[t]{2}{*}{ IL-I $\beta$} & F: 5'-ACAGATGAAGTGCTCCTTCCA-3' & 300 & 73 & [74] \\
\hline & R: 5'-GTCGGAGATTCGTAGCTGGAT-3' & 300 & & \\
\hline \multirow[t]{2}{*}{ IL-6 } & F: 5'-ACAGCCACTCACCTCTTCAG-3' & 300 & 120 & This work \\
\hline & R: 5'-GTGCCTCTTTGCTGCTTTCAC-3' & 300 & & \\
\hline \multirow[t]{2}{*}{ IL-8 } & F: 5'-GAACTGAGAGTGATTGAGAGTGGA-3' & 900 & 134 & {$[75]$} \\
\hline & R: 5'-CTCTTCAAAAACTTCTCCACAACC-3' & 300 & & \\
\hline \multirow[t]{2}{*}{ MIP-I $\beta$} & F: 5'-CCAAACCAAAAGAAGCAAGC-3' & 900 & 311 & [76] \\
\hline & R: 5'-AGAAACAGTGACAGTGGACC-3' & 300 & & \\
\hline \multirow[t]{2}{*}{ TNF- $\alpha$} & F: 5'-CCCAGGGACCTCTCTCTAATC-3' & 300 & 84 & [74] \\
\hline & R: 5'-ATGGGCTACAGGCTTGTCACT-3' & 300 & & \\
\hline
\end{tabular}


pretation, plus performed the RNA and cDNA work, and wrote the paper. $\mathrm{MK}$ developed the insert whole blood stimulation model and the DELFIA experimental protocols, and carried out some of these experiments. BT did most of the qRT-PCR analyses, several immunoblots, and helped in whole-blood stimulation experiments and release studies. CC constructed the D7S cdtABC/ltxA mutant. SA conceived the project, was responsible for its overall management and vital in drafting the manuscript.

\section{Acknowledgements}

Mrs. Elisabeth Granström is thanked for excellent technical assistance. Polyclonal antisera were generously contributed by Dr. Sun Nyunt Wai (CRP, GroEL and OmpA), Dr. Anders Johansson (LtxA), and Dr. Teresa Lagergård (CDT). This work was supported by grants from the Swedish Research Council (VR) No. 2006-06X-14747-04-3/S.A., and County Council of Västerbotten, Sweden VLL II65-2005/SA.

\section{References}

I. Slots J, Genco RJ: Black-pigmented Bacteroides species, Capnocytophaga species, and Actinobacillus actinomycetemcomitans in human periodontal disease: virulence factors in colonization, survival, and tissue destruction. J Dent Res 1984, 63(3):4|2-42I.

2. Socransky SS, Haffajee AD: The bacterial etiology of destructive periodontal disease: current concepts. J Periodontol 1992, 63(4 Suppl):322-33I

3. van Winkelhoff AJ, Slots J: Actinobacillus actinomycetemcomitans and Porphyromonas gingivalis in nonoral infections. Periodontol 2000 1999, 20:122-135.

4. Beck JD, Slade G, Offenbacher S: Oral disease, cardiovascular disease and systemic inflammation. Periodontol 20002000 , 23: $110-120$.

5. Loos BG: Systemic effects of periodontitis. Ann R Australas Coll Dent Surg 2006, 18:27-29.

6. Desvarieux M, Demmer RT, Rundek T, Boden-Albala B, Jacobs DR Jr, Sacco RL, Papapanou PN: Periodontal microbiota and carotid intima-media thickness: the Oral Infections and Vascular Disease Epidemiology Study (INVEST). Circulation 2005, I I I(5):576-582.

7. Grau AJ, Becher H, Ziegler CM, Lichy C, Buggle F, Kaiser C, Lutz R, Bultmann S, Preusch M, Dorfer CE: Periodontal disease as a risk factor for ischemic stroke. Stroke 2004, 35(2):496-50I.

8. Epstein SE, Zhou YF, Zhu J: Infection and atherosclerosis: emerging mechanistic paradigms. Circulation 1999 I 00(4): e20-28.

9. Mattila KJ, Valtonen VV, Nieminen MS, Asikainen S: Role of infection as a risk factor for atherosclerosis, myocardial infarction, and stroke. Clin Infect Dis 1998, 26(3):719-734.

10. Libby P, Ridker PM, Maseri A: Inflammation and atherosclerosis. Circulation 2002, I 05(9): I |35-I | 43.

1I. Willerson JT, Ridker PM: Inflammation as a cardiovascular risk factor. Circulation 2004, 109(2I SuppI I):II2-10.

12. Kuehn MJ, Kesty NC: Bacterial outer membrane vesicles and the host-pathogen interaction. Genes Dev 2005, I 9(22):2645-2655.

13. Wai SN, Lindmark B, Soderblom T, Takade A, Westermark M, Oscarsson J, Jass J, Richter-Dahlfors A, Mizunoe Y, Uhlin BE: Vesiclemediated export and assembly of pore-forming oligomers of the enterobacterial ClyA cytotoxin. Cell 2003, I I5(I):25-35

14. Gophna U, Ideses D, Rosen R, Grundland A, Ron EZ: OmpA of a septicemic Escherichia coli 078-secretion and convergent evolution. Int J Med Microbiol 2004, 294(6):373-38I.

15. Hellman J, Loiselle PM, Tehan MM, Allaire JE, Boyle LA, Kurnick JT, Andrews DM, Sik Kim K, Warren HS: Outer membrane protein A, peptidoglycan-associated lipoprotein, and murein lipoprotein are released by Escherichia coli bacteria into serum. Infect Immun 2000, 68(5):2566-2572.

16. Toren A, Orr E, Paitan Y, Ron EZ, Rosenberg E: The active component of the bioemulsifier alasan from Acinetobacter radi- oresistens KA53 is an OmpA-like protein. I Bacteriol 2002, I84(I): 165-170.

17. Karched M, Ihalin R, Eneslatt K, Zhong D, Oscarsson J, Wai SN, Chen C, Asikainen SE: Vesicle-independent extracellular release of a proinflammatory outer membrane lipoprotein in free-soluble form. BMC Microbiol 2008, 8(I):18.

18. Kostakioti M, Newman CL, Thanassi DG, Stathopoulos C: Mechanisms of protein export across the bacterial outer membrane. J Bacteriol 2005, I 87( | 3):4306-43 |4.

19. Schytte Blix IJ, Helgeland K, Hvattum E, Lyberg T: Lipopolysaccharide from Actinobacillus actinomycetemcomitans stimulates production of interleukin-I beta, tumor necrosis factoralpha, interleukin- 6 and interleukin- $I$ receptor antagonist in human whole blood. J Periodontal Res 1999, 34(I):34-40.

20. Cooperstock MS: Inactivation of endotoxin by polymyxin B. Antimicrob Agents Chemother 1974, 6(4):422-425.

21. Kachlany SC, Fine DH, Figurski DH: Secretion of RTX leukotoxin by Actinobacillus actinomycetemcomitans. Infect Immun 2000 68(II):6094-6100

22. Ohara M, Hayashi T, Kusunoki Y, Miyauchi M, Takata T, Sugai M: Caspase-2 and caspase-7 are involved in cytolethal distending toxin-induced apoptosis in Jurkat and MOLT-4 T-cell lines. Infect Immun 2004, 72(2):87I-879.

23. Paul-Satyaseela M, Karched M, Bian Z, Ihalin R, Boren T, Arnqvist A, Chen C, Asikainen S: Immunoproteomics of Actinobacillus actinomycetemcomitans outer-membrane proteins reveal a highly immunoreactive peptidoglycan-associated lipoprotein. I Med Microbiol 2006, 55(Pt 7):931-942.

24. Gerding MA, Ogata Y, Pecora ND, Niki $H$, de Boer PA: The transenvelope Tol-Pal complex is part of the cell division machinery and required for proper outer-membrane invagination during cell constriction in E. coli. Mol Microbiol 2007 , 63(4): $1008-1025$

25. Lazzaroni JC, Germon P, Ray MC, Vianney A: The Tol proteins of Escherichia coli and their involvement in the uptake of biomolecules and outer membrane stability. FEMS Microbiol Lett 1999, I77(2): 191-197.

26. Jeannin P, Renno T, Goetsch L, Miconnet I, Aubry JP, Delneste $Y$, Herbault N, Baussant T, Magistrelli G, Soulas C, et al.: OmpA targets dendritic cells, induces their maturation and delivers antigen into the MHC class I presentation pathway. Nat Immunol 2000, I(6):502-509.

27. Soulas C, Baussant T, Aubry JP, Delneste $Y$, Barillat N, Caron G Renno T, Bonnefoy JY, Jeannin P: Outer membrane protein A (OmpA) binds to and activates human macrophages. I Immunol 2000, 165(5):2335-2340.

28. Berlanda Scorza F, Doro F, Rodriguez-Ortega MJ, Stella M, Liberatori S, Taddei AR, Serino L, Gomes Moriel D, Nesta B, Fontana MR, et al.: Proteomics characterization of outer membrane vesicles from the extraintestinal pathogenic Escherichia coli DeltatolR IHE3034 mutant. Mol Cell Proteomics 2008, 7(3):473-485.

29. Pussinen PJ, Vilkuna-Rautiainen T, Alfthan G, Mattila K, Asikainen S: Multiserotype enzyme-linked immunosorbent assay as a diagnostic aid for periodontitis in large-scale studies. J Clin Microbiol 2002, 40(2):5। 2-5। 8

30. Vilkuna-Rautiainen T, Pussinen PJ, Mattila K, Vesanen M, Ahman $\mathrm{H}$ Dogan B, Asikainen S: Antigenically diverse reference strains and autologous strains of Actinobacillus actinomycetemcomitans are equally efficient antigens in enzyme-linked immunosorbent assay analysis. J Clin Microbiol 2002, 40( I 2):4640-4645.

31. Pussinen PJ, Vilkuna-Rautiainen T, Alfthan G, Palosuo T, jauhiainen M, Sundvall J, Vesanen M, Mattila K, Asikainen S: Severe periodontitis enhances macrophage activation via increased serum lipopolysaccharide. Arterioscler Thromb Vasc Biol 2004, 24(II):2174-2180

32. Hackett SJ, Guiver M, Marsh J, Sills JA, Thomson AP, Kaczmarski EB, Hart CA: Meningococcal bacterial DNA load at presentation correlates with disease severity. Arch Dis Child 2002, 86(I):44-46.

33. Moore WE, Moore LV: The bacteria of periodontal diseases. Periodontol 2000 1994, 5:66-77.

34. Kato S, Kowashi Y, Demuth DR: Outer membrane-like vesicles secreted by Actinobacillus actinomycetemcomitans are enriched in leukotoxin. Microb Pathog 2002, 32(I): I- 13. 
35. Saibil H: Molecular chaperones: containers and surfaces for folding, stabilising or unfolding proteins. Curr Opin Struct Biol 2000, I0(2):25I-258.

36. Thirumalai $\mathrm{D}$, Lorimer $\mathrm{GH}$ : Chaperonin-mediated protein folding. Annu Rev Biophys Biomol Struct 200I, 30:245-269.

37. Goulhen F, Hafezi A, Uitto VJ, Hinode D, Nakamura R, Grenier D, Mayrand D: Subcellular localization and cytotoxic activity of the GroEL-like protein isolated from Actinobacillus actinomycetemcomitans. Infect Immun 1998, 66 (I I):5307-53 I3.

38. Maguire M, Coates AR, Henderson B: Chaperonin 60 unfolds its secrets of cellular communication. Cell Stress Chaperones 2002 7(4):317-329.

39. Marcatili A, Cipollaro de I'Ero G, Galdiero M, Folgore A, Petrillo G: TNF-alpha, IL-I alpha, IL-6 and ICAM-I expression in human keratinocytes stimulated in vitro with Escherichia coli heatshock proteins. Microbiology I997, I 43(Pt I):45-53.

40. Paju S, Goulhen F, Asikainen S, Grenier D, Mayrand D, Uitto V: Localization of heat shock proteins in clinical Actinobacillus actinomycetemcomitans strains and their effects on epithelial cell proliferation. FEMS Microbiol Lett 2000, I 82(2):23 |-235.

41. Retzlaff C, Yamamoto Y, Hoffman PS, Friedman H, Klein TW: Bacterial heat shock proteins directly induce cytokine mRNA and interleukin-I secretion in macrophage cultures. Infect Immun 1994, 62(I 2):5689-5693.

42. Hara H, Ohta H, Inoue T, Ohashi T, Takashiba S, Murayama Y, Fukui $\mathrm{K}$ : Cell surface-associated enolase in Actinobacillus actinomycetemcomitans. Microbiol Immunol 2000, 44(5):349-356

43. Cao P, McClain MS, Forsyth MH, Cover TL: Extracellular release of antigenic proteins by Helicobacter pylori. Infect Immun 1998, 66(6):2984-2986.

44. Frisk A, Ison CA, Lagergard T: GroEL heat shock protein of Haemophilus ducreyi: association with cell surface and capacity to bind to eukaryotic cells. Infect Immun I998, 66(3): I 252-I 257

45. Galka F, Wai SN, Kusch H, Engelmann S, Hecker M, Schmeck B, Hippenstiel S, Uhlin BE, Steinert M: Proteomic characterization of the whole secretome of Legionella pneumophila and functional analysis of outer membrane vesicles. Infect Immun 2008 , 76(5): $1825-1836$.

46. Garduno RA, Garduno E, Hoffman PS: Surface-associated hsp60 chaperonin of Legionella pneumophila mediates invasion in a HeLa cell model. Infect Immun 1998, 66(10):4602-46I0.

47. Garduno RA, Faulkner G, Trevors MA, Vats N, Hoffman PS: Immu nolocalization of Hsp60 in Legionella pneumophila. J Bacterio 1998, I 80(3):505-5I3.

48. Scopio A, Johnson P, Laquerre A, Nelson DR: Subcellular localization and chaperone activities of Borrelia burgdorferi Hsp60 and Hsp70. J Bacteriol 1994, I 76(2 I):6449-6456.

49. Lewthwaite J, Skinner A, Henderson B: Are molecular chaperones microbial virulence factors? Trends Microbiol 1998 6(I I):426-428.

50. Ford PJ, Gemmell E, Chan A, Carter CL, Walker PJ, Bird PS, West MJ, Cullinan MP, Seymour GJ: Inflammation, heat shock proteins and periodontal pathogens in atherosclerosis: an immunohistologic study. Oral Microbiol Immunol 2006, 2 I (4):206-2I I

51. Fayet O, Ziegelhoffer T, Georgopoulos C: The groES and groEL heat shock gene products of Escherichia coli are essential for bacterial growth at all temperatures. J Bacteriol 1989, I 7 | (3): I 379-| 385.

52. Jensen P, Fomsgaard A, Shand G, Hindersson P, Hoiby N: Antigenic analysis of Pseudomonas aeruginosa and Pseudomonas cepacia GroEL proteins and demonstration of a lipopolysaccharide-associated GroEL fraction in P. aeruginosa. Apmis 1993, I 01 (8):621-630.

53. Hartley MG, Green M, Choules G, Rogers D, Rees DG, Newstead S Sjostedt A, Titball RW: Protection afforded by heat shock protein $\mathbf{6 0}$ from Francisella tularensis is due to copurified lipopolysaccharide. Infect Immun 2004, 72(7):4 I09-4 I I 3.

54. Osterloh A, Kalinke U, Weiss S, Fleischer B, Breloer M: Synergistic and differential modulation of immune responses by $\mathrm{Hsp} 60$ and lipopolysaccharide. I Biol Chem 2007, 282(7):4669-4680.

55. Packard RR, Libby P: Inflammation in atherosclerosis: from vascular biology to biomarker discovery and risk prediction. Clin Chem 2008, 54(I):24-38.

56. Brogan JM, Lally ET, Poulsen K, Kilian M, Demuth DR: Regulation of Actinobacillus actinomycetemcomitans leukotoxin expres- sion: analysis of the promoter regions of leukotoxic and minimally leukotoxic strains. Infect Immun 1994, 62(2):50 I-508.

57. Korhonen TK, Valtonen MV, Parkkinen J, Vaisanen-Rhen V, Finne J, Orskov F, Orskov I, Svenson SB, Makela PH: Serotypes, hemolysin production, and receptor recognition of Escherichia coli strains associated with neonatal sepsis and meningitis. Infect Immun 1985, 48(2):486-49|

58. Kaplan JB, Meyenhofer MF, Fine DH: Biofilm growth and detachment of Actinobacillus actinomycetemcomitans. I Bacteriol 2003, I 85(4): | 399-| 404

59. Fujise O, Wang Y, Chen W, Chen C: Adherence of Aggregatibacter actinomycetemcomitans via serotype-specific polysaccharide antigens in lipopolysaccharides. Oral Microbiol Immunol 2008, 23(3):226-233.

60. Wang Y, Goodman SD, Redfield RJ, Chen C: Natural transformation and DNA uptake signal sequences in Actinobacillus actinomycetemcomitans. J Bacteriol 2002, I 84( I 3):3442-3449.

6I. Sternberg N, Sauer B, Hoess R, Abremski K: Bacteriophage P I cre gene and its regulatory region. Evidence for multiple promoters and for regulation by DNA methylation. I $\mathrm{Mol} B \mathrm{Biol}$ 1986, I87(2):|97-2|2.

62. Mangan SH, Campenhout AV, Rush C, Golledge J: Osteoprotegerin upregulates endothelial cell adhesion molecule response to tumor necrosis factor-alpha associated with induction of angiopoietin-2. Cardiovasc Res 2007, 76(3):494-505.

63. Gao B, Tsan MF: Endotoxin contamination in recombinant human heat shock protein 70 (Hsp 70) preparation is responsible for the induction of tumor necrosis factor alpha release by murine macrophages. J Biol Chem 2003, 278(I): I74-I79.

64. Gao B, Tsan MF: Recombinant human heat shock protein 60 does not induce the release of tumor necrosis factor alpha from murine macrophages. J Biol Chem 2003, 278(25):22523-22529.

65. Gao B, Wang Y, Tsan MF: The heat sensitivity of cytokine-inducing effect of lipopolysaccharide. J Leukoc Biol 2006, 80(2):359-366.

66. Kaplan JB, Ragunath C, Ramasubbu N, Fine DH: Detachment of Actinobacillus actinomycetemcomitans biofilm cells by an endogenous beta-hexosaminidase activity. I Bacteriol 2003 I 85( (16):4693-4698.

67. Johansson A, Sandstrom G, Claesson R, Hanstrom L, Kalfas S: Anaerobic neutrophil-dependent killing of Actinobacillus actinomycetemcomitans in relation to the bacterial leukotoxicity. Eur J Oral Sci 2000, I 08(2): | 36- | 46.

68. Ihalin $\mathrm{R}$, Karched $\mathrm{M}$, Eneslatt $\mathrm{K}$, Asikainen S. Characterization of immunoaffinity purified peptidoglycan-associated lipoprotein of Actinobacillus actinomycetemcomitans. J Chromatogr B Analyt Technol Biomed Life Sci 2006, 83 I( I-2): I I 6-I25.

69. Henning U, Schwarz H, Chen R: Radioimmunological screening method for specific membrane proteins. Anal Biochem 1979 , 97(I): I53-I57.

70. Wising C, Svensson LA, Ahmed HJ, Sundaeus V, Ahlman K, Jonsson IM, Molne L, Lagergard T: Toxicity and immunogenicity of purified Haemophilus ducreyi cytolethal distending toxin in a rabbit model. Microb Pathog 2002, 33(2):49-62.

7I. Kouokam JC, Wai SN, Fallman M, Dobrindt U, Hacker J, Uhlin BE: Active cytotoxic necrotizing factor I associated with outer membrane vesicles from uropathogenic Escherichia coli. Infect Immun 2006, 74(4):2022-2030.

72. Saarela M, Asikainen S, Alaluusua S, Pyhala L, Lai CH, Jousimies-Somer $\mathrm{H}$ : Frequency and stability of mono- or poly-infection by Actinobacillus actinomycetemcomitans serotypes a, b, c, d or e. Oral Microbiol Immunol 1992, 7(5):277-279.

73. Rued I C, Wick G, Wolf $\mathrm{H}$ : A novel and sensitive method for the detection of secreted cell products using time-resolved fluorescence. J Immunol Methods I994, I 68(I):6I-67.

74. Stordeur $P$, Poulin LF, Craciun L, Zhou L Schandene L, de Lavareille A, Goriely S, Goldman M: Cytokine mRNA quantification by real-time PCR. J Immunol Methods 2002, 259(I-2):55-64.

75. Ohki R, Yamamoto K, Mano H, Lee RT, Ikeda U, Shimada K. Identification of mechanically induced genes in human monocytic cells by DNA microarrays. J Hypertens 2002, 20(4):685-69l.

76. Hirota M, Moro O: MIP-I beta, a novel biomarker for in vitro sensitization test using human monocytic cell line. Toxicol In Vitro 2006, 20(5):736-742. 